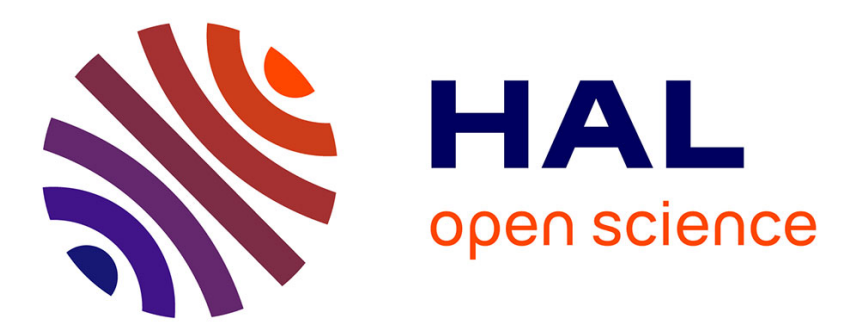

\title{
Lactobacillus plantarum strains isolated from traditional Greek cheese. Taxonomic characterization and screening for enzyme activities
}

\author{
I Ztaliou, E Tsakalidou, N Tzanetakis, G Kalantzopoulos
}

\section{- To cite this version:}

I Ztaliou, E Tsakalidou, N Tzanetakis, G Kalantzopoulos. Lactobacillus plantarum strains isolated from traditional Greek cheese. Taxonomic characterization and screening for enzyme activities. Le Lait, 1996, 76 (3), pp.209-216. hal-00929481

\section{HAL Id: hal-00929481 https://hal.science/hal-00929481}

Submitted on 1 Jan 1996

HAL is a multi-disciplinary open access archive for the deposit and dissemination of scientific research documents, whether they are published or not. The documents may come from teaching and research institutions in France or abroad, or from public or private research centers.
L'archive ouverte pluridisciplinaire HAL, est destinée au dépôt et à la diffusion de documents scientifiques de niveau recherche, publiés ou non, émanant des établissements d'enseignement et de recherche français ou étrangers, des laboratoires publics ou privés. 


\title{
Lactobacillus plantarum strains isolated from traditional Greek cheese. Taxonomic characterization and screening for enzyme activities
}

\author{
I Ztaliou' ${ }^{1}$ E Tsakalidou²*, N Tzanetakis', \\ G Kalantzopoulos ${ }^{2}$
}

\author{
${ }^{1}$ Department of Food Science and Technology, Aristotle University of Thessaloniki, \\ 54006 Thessaloniki; ${ }^{2}$ Laboratory of Dairy Research, Department of Food \\ Science and Technology, Agricultural University of Athens, \\ lera Odos 75, 11855 Athens, Greece
}

(Received 6 June 1995; accepted 1 December 1995)

\begin{abstract}
Summary - A total of 16 mesophilic homofermentative lactobacilli were isolated from Xynotyri, a traditional Greek cheese. Identification of strains was performed by phenotypic methods and by SDS-polyacrylamide gel electrophoresis of whole-cell proteins; strains were found to belong to the Lactobacillus plantarum species. Peptidase and esterase activities were detected spectrophotometrically and electrophoretically in the cell-free extracts of the strains, using synthetic substrates. The proteolytic activity of whole cells in milk, as well as the proteolytic activity of cell-free extracts on whole bovine casein were examined. Significant differences within the species were observed, allowing the selection of technologically interesting strains.
\end{abstract}

Lactobacillus plantarum / taxonomy / enzyme activity

Résumé - Souches de $L$ plantarum isolées à partir d'un fromage grec traditionnel. $\dot{A}$ partir d'un fromage traditionnel grec, nous avons isolé 16 souches de lactobacilles thermophiles homofermentaires. L'identification des souches a été faite par leurs caractères phénotypiques ainsi que par électrophorèse en SDS polyacrylamide des protéines totales. Les souches appartenaient aux différentes espèces du Lactobacillus plantarum. Nous avons aussi étudié leur activité peptidasique et estérasique par spectophotométrie et par électrophorèse de l'extrait cellulaire des souches avec des substrats synthétiques. L'activité protéolytique des cellules dans le lait, ainsi que de l'extrait des cellules sur la caséine totale de vache a été étudiée. Des différences significatives entre les souches ont été observées, permettant une sélection selon leur intérêt technologique.

Lactobacillus plantarum / taxonomie / activité enzymatique

*Correspondence and reprints. 


\section{INTRODUCTION}

Mesophilic lactobacilli constitute most of the non-starter lactic acid bacterial population in many varieties of cheese. These microorganisms typically gain entrance through post-pasteurization contamination, but may also constitute part of the raw milk flora and survive pasteurization (Chapman and Sharpe, 1981; Turner et al, 1986). Mesophilic lactobacilli represent one of the few lactic acid bacteria groups capable of growing to high cell densities under the selective conditions of cheese ripening (low $E_{h}$, low $\mathrm{pH}$, limited carbohydrate). They can utilize metabolites such as lactate, amino acids, ribose and $\mathrm{N}$-acetylamino sugars as a nutrient source more effectively than other starter or nonstarter lactic acid bacteria. This may partially explain their dominance during ripening (Thomas, 1987).

Nevertheless, the exact role played by lactobacilli during cheese maturation is still not fully understood. Several groups have undertaken different kinds of approaches in order to evaluate the metabolic activities of lactobacilli and their potential significance during cheese ripening (Law et al, 1976; El Soda et al, 1981). Lactobacillus plantarum has been isolated in large numbers from ripening cheeses (Tzanetakis et al, 1987; Tzanetakis, 1990; Tzanetakis and Litopoulou Tzanetaki, 1992). However, the knowledge of its proteolytic and lipolytic system is rather limited (Oterholm et al, 1972; El Soda et al, 1983; De Giori et al, 1985; El Soda et al, 1986a,b,c; Broome and Hickey, 1990a,b; Khalid and Marth, 1990; Peterson et al, 1990).

Xynotyri cheese is a traditional Greek cheese prepared from ewe's or goat's milk with the use of naturally dominating microflora. No data are available concerning the influence of mesophilic lactobacilli on the quality of Xynotyri cheese, as well as their level and growth kinetics. The objectives of this study were to isolate strains of Lacto- bacillus plantarum ( $L$ plantarum) from traditional Xynotyri cheese and to characterize them by screening for proteolytic and lipolytic activities. This might serve as a basis for the selection of representative strains to be used in subsequent studies on cheese ripening.

\section{MATERIALS AND METHODS}

\section{Preparation of Xynotyri cheese}

Fresh milk (ewe's or goat's) is mixed in 1:1 ratio with milk obtained the previous evening, which was stored at approximately $10^{\circ} \mathrm{C}$. To the milk mixture (fat content $4.5-5 \%$, acidity $35-40^{\circ} \mathrm{D}$ ) liquid rennet is added ( $5 \mathrm{~mL}$ per $100 \mathrm{~kg}$ milk). After coagulation for $20 \mathrm{~h}$ at $8-10^{\circ} \mathrm{C}$, the curd is cut in cubes $(1-2 \mathrm{~cm})$, rested for $6 \mathrm{~h}$ and then drained through a cheese cloth. The next day the curd is knitted, salted and packed in cans. The cheese is consumed either as fresh cheese or as ripened cheese after 3 months.

\section{Isolation and identification of strains}

All strains were originally isolated from Xynotyri cheese by standard microbiological procedures for the detection of lactic acid bacteria. They were deposited in the ACA-DC Collection (Laboratory of Dairy Research, Agricultural University of Athens). The phenotypic identification was performed according to Sharpe and Fryer (1965), Sharpe (1979), and Kandler and Weiss (1986). Carbohydrate fermentation was determined using the API $50 \mathrm{CHL}$ galleries (BioMerieux, Vercieu, France). Strains were stored at $-30^{\circ} \mathrm{C}$ in MRS broth (De Man et al, 1960), containing $15 \%$ glycerol.

\section{Preparation of the cell-free extracts}

Strains were subcultured twice in MRS broth. Final growth was performed in MRS broth ( $1 \%$ inoculum), at $30^{\circ} \mathrm{C}$. Early stationary phase cells $(16 \mathrm{~h})$ were collected from the growth medium by centrifugation $\left(12000 \mathrm{~g}, 10 \mathrm{~min}, 4^{\circ} \mathrm{C}\right.$ ). The pellet obtained was washed three times with $0.05 \mathrm{~mol} / \mathrm{L}$ Tris- $\mathrm{HCl}$ buffer $(\mathrm{pH} 7.0)$, containing $0.1 \mathrm{~mol} / \mathrm{L} \mathrm{NaCl}$. Subsequently, it was resuspended in $0.05 \mathrm{~mol} / \mathrm{L}$ Tris- $\mathrm{HCl}$ buffer $(\mathrm{pH} 8.0)$, containing $2 \mathrm{mg} / \mathrm{mL}$ lysozyme, and incubated for $2 \mathrm{~h}$ at $37^{\circ} \mathrm{C}$. The supernatant obtained after cen- 
trifugation $\left(12000 \mathrm{~g}, 15 \mathrm{~min}, 4^{\circ} \mathrm{C}\right.$ ) was designated as the cell-free extract.

\section{Measurement of peptidase and esterase activities}

For the detection of peptidase activities five substrates were used: lysine-, leucine-, phenylalanine-, $\mathrm{N}$-acetyl-alanine- and $\alpha$-glutamic acid-4nitroanilide (Sigma, St-Louis, USA). For the screening of esterolytic enzymes five 4-nitrophenol derivatives were used: 4-nitrophenyl-acetate (C2), -butyrate (C4), -caproate (C6), -caprylate (C8) and -caprate (C10) (Sigma, St Louis, USA). For the qualitative detection of enzyme activities, cell-free extract $(25 \mu \mathrm{L})$ and substrate solution ( $25 \mu \mathrm{L} ; 10 \mathrm{mmol} / \mathrm{L}$ in methanol) were incubated in $200 \mu \mathrm{L} 0.05 \mathrm{~mol} / \mathrm{L}$ phosphate buff-

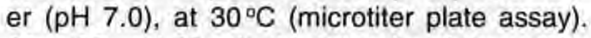
After 30 and 60 min the intensity of the yellow colour against the blank measurement was visually recorded on a scale from 1 to 4 . Subsequently quantitative enzyme tests were performed for all cell-free extracts scoring higher than 1 on this scale. Cell-free extract $(50 \mu \mathrm{L})$ and substrate solution $(50 \mu \mathrm{L} ; 10 \mathrm{mmol} / \mathrm{L}$ in methanol) were incubated in $400 \mu \mathrm{L} 0.05 \mathrm{~mol} / \mathrm{L}$ phosphate buffer $(\mathrm{pH} 7.0)$, at $30^{\circ} \mathrm{C}$. The activity was spectrophotometrically assayed at $410 \mathrm{~nm}$ by measuring the degree of substrate hydrolysis. A unit (U) of enzyme activity was defined as the amount of enzyme producing $1 \mu \mathrm{mol} 4$-nitroaniline or 4-nitrophenol $\left(\varepsilon_{410}=8800\right.$ and $7660 \mathrm{~L}$ $\mathrm{mol}^{-1} \mathrm{~cm}^{-1}$ respectively) per min. Specific activity was defined as the number of units per $\mathrm{mg}$ of protein. The Bio-Rad Protein Assay Reagent kit (Bio-Rad Laboratories, Munich, Germany) was used for the determination of protein, with bovine serum albumin as standard.

\section{Polyacrylamide gel electrophoresis}

SDS-PAGE (Laemmli, 1970) (10\% acrylamide gels; $0.025 \mathrm{~mol} / \mathrm{L}$ Tris- $0.19 \mathrm{~mol} / \mathrm{L}$ glycine buffer, $\mathrm{pH}$ 8.3) was used to obtain the protein fingerprints of the strains tested. Phosphorylase $b(92500)$, bovine serum albumin $(67000)$, egg albumin (45000), and carbonic anhydrase $(29000)$ were used as molecular mass markers.

Post-electrophoretic detection of the enzyme activities was performed using two different electrophoretic systems: 1) under the same conditions as before (Laemmli system), but in the absence of SDS and 2-mercaptoethanol; and 2) electrophoresis on a $7 \%$ polyacrylamide gel (continuous system), without SDS and 2mercaptoethanol, in $0.1 \mathrm{~mol} / \mathrm{L}$ phosphate buffer ( $\mathrm{pH} 7.2)$ (Cooper, 1981). In both cases, activity was detected directly on the gel (Miller and Mackinnon, 1974; Harper et al, 1980). In the case of peptidases lysine- and leucine- $\beta$-naphthylamide were used as substrates and Fast Garnet GBC as colour compound; in the case of esterases the a-naphthyl esters of acetate and butyrate were used as substrates, with Fast Red TR as colour compound.

\section{Determination of proteolytic activity}

Strains were grown in 10\% sterile skim milk $(1 \%$ inoculum), at $30^{\circ} \mathrm{C}$; samples were taken after 3 and 6 days, and mixed with an equal volume of $12 \%$ TCA solution. After $15 \mathrm{~min}$ at room temperature, the $6 \%$ TCA soluble fraction was separated by centrifugation $(12000 \mathrm{~g}, 5 \mathrm{~min}$ ) and the amino acids/peptides produced were determined using the o-phthaldialdehyde method (Church et al, 1983). Results were expressed in $\mathrm{L}$-glycine equivalent $(\mathrm{mmol} / \mathrm{L})$. The sediment was dissolved in $8 \mathrm{~mol} / \mathrm{L}$ urea and subjected to polyacrylamide gel electrophoresis, in the presence of urea (Andrews, 1983).

Three strains were tested for proteolytic activity on whole bovine casein. Casein solution $(50 \mu \mathrm{L}$; $10 \mathrm{mg} / \mathrm{mL}$ ) and $50 \mu \mathrm{L}$ cell-free extract were incubated in $100 \mu \mathrm{L} 0.25 \mathrm{~mol} / \mathrm{L}$ Tris- $\mathrm{HCl}$ buffer $(\mathrm{pH}$ 6.8 ) at $37^{\circ} \mathrm{C}$. The reaction was stopped (after 24 and $48 \mathrm{~h}$ ) by $200 \mu \mathrm{L} 12 \%$ TCA. After $15 \mathrm{~min}$ at room temperature, the $6 \%$ TCA soluble fraction was separated by centrifugation $(12000 \mathrm{~g}$, $5 \mathrm{~min}$ ). Sediment as well as supernatant obtained were subjected to the same analysis as described above.

\section{RESULTS AND DISCUSSION}

\section{Identification of strains}

The phenotypic characteristics of the isolates are shown in table I. It is obvious that the phenotypic characteristics of the 16 isolates were more than $90 \%$ in agreement with those described by Kandler and Weiss (1986) for the L plantarum species, which is the predominant lactobacillus species in Greek traditional cheeses (Tzaneta- 
kis et al, 1987; Tzanetakis, 1990; Litopoulou-Tzanetaki and Tzanetakis, 1992; Tzanetakis and Litopoulou-Tzanetaki, 1992). The SDS-PAGE analysis confirmed the phenotypic identification. The identification of strains was performed by visual comparison of their electrophoretic patterns. All strains possessed similar strong bands with the same mobility, and only in some cases a few faint bands were different (fig 1a, b). L plantarum ACA-DC 142 was used as reference strain; this was previously identified phenotypically as well as by the SDS-PAGE technique (Tsakalidou et al, 1994). The protein profiles of the strains tested were identical with the electrophoretic pattern of the reference strain (fig 1c).

\section{Peptidase and esterase activities}

Using the microtiter plate assay, none of the strains showed high activity on phenylalanine-, $\mathrm{N}$-acetyl-alanine- and aglutamic acid-4-nitroanilide (peptidases) or on 4-nitrophenyl-caproate (C6), -caprylate (C8) and caprate (C10) (esterases). Therefore, only lysine- and leucine-4-nitroanilide as well as 4-nitrophenyl-acetate and -butyrate were used for the spectrophotometric determination of peptidase and esterase activities respectively (table II).

According to the results obtained from the spectrophotometric detection, all strains were more active on lysine-4-nitroanilide (hydrophilic and basic character), than on leucine-4-nitroanilide (hydrophobic character). Strains ACA-DC 271, 274, 280, 283 and 288 displayed the highest peptidase activities; they ranged from 146 to 198 $\mathrm{U} / \mathrm{g}$ on lysine-4-nitroanilide and from 42 to $64 \mathrm{U} / \mathrm{g}$ on leucine-4-nitroanilide. Absence of activity on phenylalanine-4-nitroanilide might be due to the hydrophobic character of the substrate, while no activity on $\alpha$-glutamic acid-4-nitroanilide is due to its hydrophilic but acidic character. Nevertheless, Peterson et al (1990) reported that cell-free extracts of $L$ plantarum displayed higher
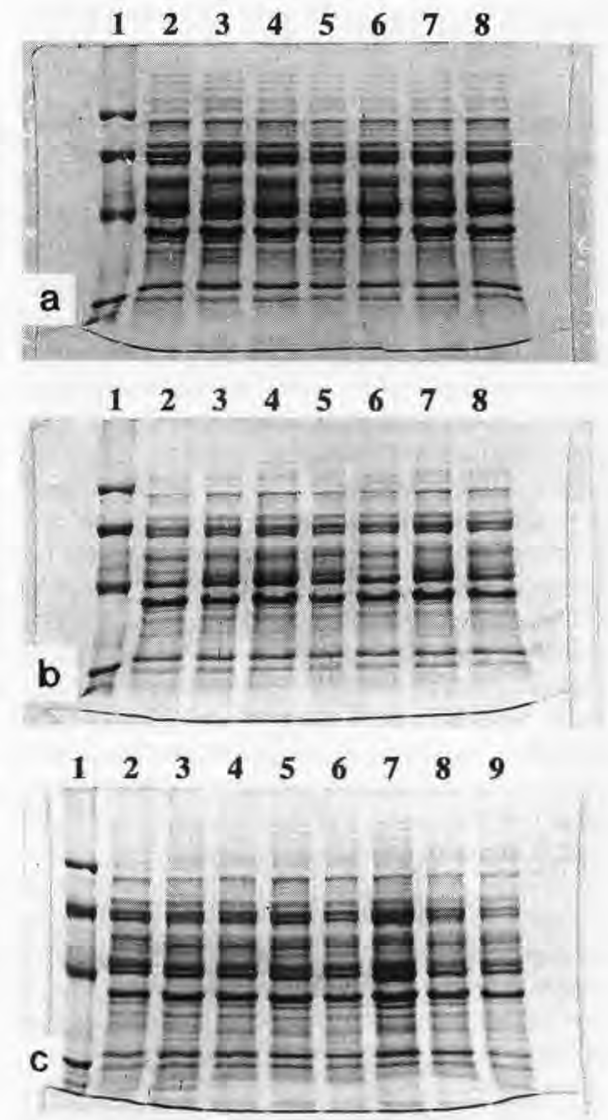

Fig 1. SDS-polyacrylamide gel electrophoresis ( $10 \%$ acrylamide, $25 \mathrm{mmol} / \mathrm{L}$ Tris $-0.19 \mathrm{~mol} / \mathrm{L}$ glycine, $\mathrm{pH}$ 8.3) of the cell-free extracts from the ACA-DC Lactobacillus plantarum strains. Lanes: 1 , Molecular mass markers $(92,67,45$ and 29 kDa). a. Lanes: 2,$269 ; 3,270 ; 4,271 ; 5,274 ; 6,275$; 7,276 ; and 8, 278. b. Lanes: 2,$279 ; 3,280 ; 4,282 ; 5$, $283 ; 6,284 ; 7,285$; and 8, 287. c. Lanes: 2, 288; 3 , $290 ; 4,271 ; 5$, Lactobacillus plantarum reference strain 142; 6, 276; 7, 280; 8, 284; and 9, 287.

Électrophorèse sur SDS polyacrylamide (10\% acrylamide, $25 \mathrm{mmol} / \mathrm{L}$ Tris-0,19 moll glycine, $\mathrm{pH}$ $8,3)$ de l'extrait cellulaire des souches de Lactobacillus plantarum ACA-DC. 1: Marqueurs de masse moléculaire $(92,67,45$ et $29 \mathrm{kDa})$. a) $2: 269 ; 3: 270 ; 4: 271 ; 5: 274 ; 6: 275 ; 7:$ 276 et $8: 278$. b) $2: 279 ; 3: 280 ; 4: 282 ; 5$ : $283 ; 6: 284 ; 7: 285$ et $8: 287$. c) $2: 288 ; 3:$ $290 ; 4: 271 ; 5$ : Lactobacillus plantarum souche de référence $142 ; 6: 276 ; 7: 280$; $8: 284$ et $9: 287$. 
Table I. Phenotypic characteristics of the 16 Lactobacillus plantarum strains.

Caractères phénotypiques de 16 souches de Lactobacillus plantarum.

\begin{tabular}{lcc}
\hline Characteristics & $\begin{array}{c}\text { Kandler } \\
\text { and Weiss } \\
(1986)\end{array}$ & $\begin{array}{c}\text { Present } \\
\text { study }\end{array}$ \\
\hline Growth at $15^{\circ} \mathrm{C}$ & + & + \\
Growth at $45^{\circ} \mathrm{C}$ & $\mathrm{a}$ & + \\
$\mathrm{CO}_{2}$ from glucose & - & - \\
Arginine hydrolysis & - & - \\
Esculine hydrolysis & + & + \\
Acid from gluconate & + & $4+, 12-$ \\
Amygdaline & + & + \\
D-Arabinose & + & + \\
Cellobiose & + & + \\
Lactose & + & + \\
Maltose & + & + \\
Mannitol & + & + \\
D-Mannose & + & + \\
Melezitose & a & + \\
Melibiose & + & + \\
D-Raffinose & + & $14+, 2-$ \\
Rhamnose & - & - \\
Ribose & + & + \\
Salicine & + & + \\
Sorbitol & + & $4+, 12-$ \\
Saccharose & + & + \\
Trehalose & + & $15+, 1-$ \\
D-Xylose & + & - \\
& & + \\
\hline & + &
\end{tabular}

(a): Variable reaction according to Sharpe (1979).

specific activity towards hydrophobic dipeptides as compared to hydrophilic dipeptides and 4-nitroaniline derivatives. Very low hydrolysis of $\mathrm{N}$-acetyl-alanine-4-nitroanilide might be an indication that the strains lacked endopeptidase activity. According to El Soda et al (1983), the intracellular peptidase system of $L$ plantarum consisted of aminopeptidase and dipeptidase activities, while no carboxypeptidase or endopeptidase activities were present. Similar results have also been reported (Broome and Hickey, 1990a).

Low esterase activities were determined with 4-nitrophenyl-acetate and -butyrate. Between the two substrates no considerable differences were observed. Strains
ACA-DC 271, 274 and 288 showed the highest esterase activities. These ranged from 66 to $83 \mathrm{U} / \mathrm{g}$ on 4-nitrophenyl-acetate and from 29 to $44 \mathrm{U} / \mathrm{g}$ on 4-nitrophenyl-butyrate. Previous studies on the lipolytic system of $L$ plantarum showed that this is weak and specific towards short chain fatty acids. According to Fryer et al (1967), L plantarum lipase is close to the cell surface and so readily released. Singh et al (1973) claimed that the species possessed an endocellular lipase, which can hydrolyse tributyrin extensively but tripalmitin and triolein only sparingly. Similar results have been also reported (Oterholm et al, 1968; El Soda et al, 1986b). El Soda et al (1986a) used 2- and 4-nitrophenyl derivatives of fatty acids as substrates for the detection of esterolytic activities in L plantarum, and re-

Table II. Peptidase and esterase activities (U/g) of the 16 Lactobacillus plantarum strains.

Activité peptidasique et esterasique $(\mathrm{U} / \mathrm{g})$ de 16 souches $d u$ Lactobacillus plantarum.

\begin{tabular}{lrrrr}
\hline Strain & Lys-AP Leu-AP C2-ES & C4-ES \\
\hline ACA-DC 269 & 114 & 36 & 28 & 32 \\
ACA-DC 270 & 138 & 39 & 0 & 5 \\
ACA-DC 271 & 198 & 64 & 83 & 44 \\
ACA-DC 274 & 168 & 53 & 73 & 30 \\
ACA-DC 275 & 117 & 32 & 26 & 29 \\
ACA-DC 276 & 137 & 38 & 13 & 19 \\
ACA-DC 278 & 133 & 36 & 33 & 35 \\
ACA-DC 279 & 138 & 38 & 0 & 3 \\
ACA-DC 280 & 168 & 42 & 18 & 25 \\
ACA-DC 282 & 124 & 32 & 6 & 6 \\
ACA-DC 283 & 152 & 47 & 3 & 0 \\
ACA-DC 284 & 50 & 9 & 20 & 19 \\
ACA-DC 285 & 123 & 32 & 9 & 12 \\
ACA-DC 287 & 106 & 25 & 29 & 20 \\
ACA-DC 288 & 146 & 42 & 66 & 29 \\
ACA-DC 290 & 51 & 11 & 14 & 39
\end{tabular}

Lys-AP, L-lysine-4-nitroanilide; Leu-AP, L-leucine-4nitroanilide; C2-ES: 4-nitrophenyl-acetate; C4-ES, 4nitrophenyl-butyrate.

Values are the mean of three experiments; standard error less than 0.05 .

Valeurs moyennes de trois essais ; erreur : moins de 0,05 . 
ported that the rate of hydrolysis decreased with the increase in the number of carbon atoms (from $\mathrm{C} 2$ to $\mathrm{C} 5$ ); $L$ plantarum strains showed inability to hydrolyse 2- and 4-nitrophenyl-caproate (C6) and -caprylate (C8). These data are in agreement with the results obtained in the present study.

Histochemical staining after discontinuous electrophoresis $(\mathrm{pH} 8.3)$ revealed no peptidase bands, when lysine- or leucine- $\beta$-naphthylamide were used as substrates; this might be due to the alkaline $\mathrm{pH}$ of the electrophoretic system. Peptidase activities could only be detected on the one-gel electrophoretic system $(\mathrm{pH} 7.2)$; almost all strains gave one ill-defined, diffuse band with $R_{f}=0.33$ for both substrates. This band was stronger in the case of ACA-DC 271 and 274 strains. On the contrary, histochemical staining gave active esterase bands on the discontinuous system ( $\mathrm{pH} 8.3$ ) for both $\alpha$-naphthyl-acetate and -butyrate, with $R_{f}=0.22$ and $R_{f}=0.42$ respectively. After prolonged incubation of the gels in the staining solution, three more weak bands were observed for acetate, in the case of ACA-DC 271 and 274 strains $\left(R_{f}=0.60,0.70,0.84\right)$.

\section{Proteolytic activity}

The proteolytic activity of the strains when grown in skim milk was generally very low. Even after 6 days of incubation, no degradation of milk casein was observed electrophoretically. The concentrations of the free amino acids/peptides determined in the $6 \%$ TCA soluble material were also very low. Only three strains, ACA-DC 274, 284 and 288 showed proteolytic activity under these conditions (table III). For this reason the cell-free extracts of these strains were tested for their ability to hydrolyse whole bovine casein in aqueous solution. After a 48$h$ incubation, the free amino acid level was higher than in the case of milk casein hydrolysis (table III) and casein degradation was detectable after electrophoresis.
Table III. Milk casein and whole bovine casein hydrolysis by three Lactobacillus plantarum strains, determined in amino acid equivalent in the $6 \%$ TCA soluble material. Results are expressed as L-glycine ( $\mathrm{mmol} / \mathrm{L}$ )

L'hydrolyse de la caséine du lait et de la caseine bovine totale par 3 souches du Lactobacillus plantarum. Les valeurs sont exprimées en equivalent en aminoacides solubles dans le TCA $6 \%$. Les résultats sont exprimées en $\mathrm{mmol} / \mathrm{L}$ de L-glycine.

\begin{tabular}{cccccc}
\hline & \multicolumn{2}{c}{ Milk } & \multicolumn{2}{c}{$\begin{array}{c}\text { Whole bovine } \\
\text { casein }\end{array}$} \\
\hline Strain & 3 days & 6 days & $24 \mathrm{~h}$ & $48 \mathrm{~h}$ \\
\hline ACA-DC 274 & 0.52 & 0.86 & 3.40 & 4.16 \\
ACA-DC 284 & 0.79 & 1.10 & 1.36 & 2.48 \\
ACA-DC 288 & 0.62 & 0.92 & 5.00 & 6.80 \\
\hline
\end{tabular}

Values are the mean of three experiments; standard error less than 0.05 .

Valeurs moyennes de trois essais ; erreur : moins de 0,05 .

All three strains hydrolysed $\beta$-casein more easily than $\alpha$-casein (fig 2). Whole cells of strain ACA-DC 284, which showed the lowest peptidase activities (table II), hydrolysed milk casein more readily than the whole cells of strains ACA-DC 274 and 288 , which belonged to the group of strains with the higher peptidase activities. On the contrary, the cell-free extracts of strains ACA-DC 274 and 288 attacked whole bovine casein more easily than the cell-free extract of strain ACA-DC 284. This is an indication that the latter strain possessed a cell-wall associated proteinase; its low hydrolysis rate on whole bovine casein might be due to its instability under the cell lysis conditions.

According to El Soda et al (1986c), $L$ plantarum possessed an induced cellwall associated proteinase, but this activity was lower than that of $L$ casei. De Giori et al (1985) claimed that $L$ plantarum strains showed greater activity on casein at 15 and $45^{\circ} \mathrm{C}$, and in $\mathrm{pH}$ range between 5.60 and 6.20. Khalid and Marth (1990) reported that $L$ plantarum preferentially degraded $\beta$-ca- 


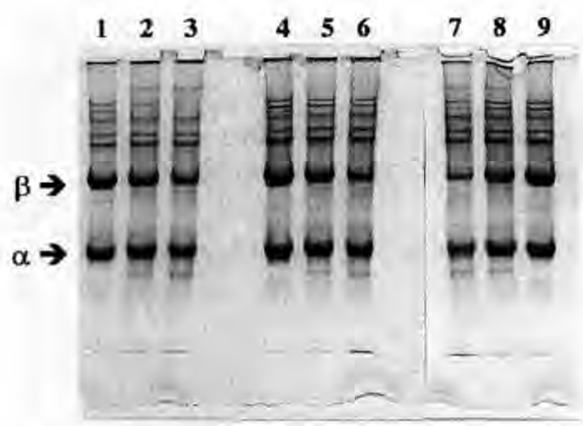

Fig 2 Urea-polyacrylamide gel electrophoresis (12\% acrylamide, $25 \mathrm{mmol} / \mathrm{L}$ Tris- $0.19 \mathrm{~mol} / \mathrm{L}$ glycine, $\mathrm{pH}$ 8.3) of whole bovine casein after incubation with cell-free extracts of the ACA-DC Lactobacillus plantarum strains. Lanes: $1,284 / 0 \mathrm{~h} ; 2$, $284 / 24$ h; $3,284 / 48$ h; $4,274 / 0$ h; $5,274 / 24$ h; 6 , $274 / 48$ h; $7,288 / 48$ h; $8: 288 / 24,9: 288 / 0$.

Électrophorèse sur gel d'urée-polyacrylamide (12\% acrylamide, $25 \mathrm{mmol} / \mathrm{L}$ Tris-0,19 mol/L glycine, $\mathrm{pH} 8,3$ ) de la caséine bovine après incubation avec l'extrait cellulaire des souches de Lactobacillus plantarum ACA-DC. $1: 284 / 0 \mathrm{~h}$; $2: 284 / 24 h ; 3: 284 / 48 h ; 4: 274 / 0 h ; 5: 274 / 24 h$; $6: 274 / 48 h ; 7: 288 / 48 h ; 8: 288 / 24 h ; 9:$ $288 / 0 \mathrm{~h}$.

sein of milk, whereas $\alpha_{s 1}$-casein was partially hydrolysed by some strains; similar results on the proteolytic activity of $L$ plantarum have been also reported (EI Soda et al, 1983; Broome and Hickey, 1990b). Results presented in the present work confirmed these data.

From the overall study it is obvious that the $L$ plantarum strains examined in the present study, displayed rather low peptidase, esterase and proteinase activities. Nevertheless, two out of the 16 strains tested, namely strains ACA-DC 271 and 274 showed considerable peptidase as well as esterase activities. Strain ACA-DC 284 displayed proteolytic activity, obviously due to a cell-wall associated proteinase. These findings indicate the potential contribution of $L$ plantarum in the ripening changes of cheese and may serve as a basis for the selection of representative strains to be used in subsequent studies on cheese ripening.

\section{ACKNOWLEDGMENTS}

The authors thank the Greek Ministry of Industry, Energy and Technology for financial support.

\section{REFERENCES}

Andrews AT (1983) Proteinases in normal bovine milk and their action on caseins. J Dairy Res 50, 45-55

Broome MC, Hickey MW (1990a) Peptidase activity of selected non-starter lactobacilli. In: Brief Commun XXIII Int Dairy Congr, Montreal. IDF 259 (483) Brussels, Belgium

Broome MC, Hickey MW (1990b) Proteolytic activity of selected non-starter lactobacilli. In: Brief Commun XXIII Int Dairy Congr, Montreal. IDF 260 (485) Brussels, Belgium

Chapman HR, Sharpe ME (1981) Microbiology of cheese. In: Dairy Microbiology (Robinson RK, ed) Applied Science Publishers, London

Church FC, Swaisgood HE, Porter DH, Catignani GL (1983) Spectrophotometric assay using ophthaldialdehyde for determination of proteolysis in milk and isolated milk proteins. $J$ Dairy Sci 66, 1219-1227

Cooper TG (1981) Elektrophorese. In: Biochemische Arbeitsmethoden. (Cooper TG, ed) Walter de Gruyter, Berlin

De Giori GS, De Valdez GF, De Ruiz Holgado AP, Oliver $\mathrm{G}$ (1985) Effect of $\mathrm{pH}$ and temperature on the proteolytic activity of lactic acid bacteria. J Dairy Sci $68,2160-2164$

De Man JC, Rogosa M, Sharpe ME (1960) A medium for the cultivation of lactobacilli. J Appl Bacteriol 23, 130-135

El Soda M, Desmazeaud MJ, Aboudonia S, Kamal $N$ (1981) Acceleration of cheese ripening by the addition of whole cells or cell free extracts from Lactobacillus casei to the cheese curd. Milchwissenschaft $36,140-142$

El Soda M, Said H, Desmazeaud, MJ, Mashaly R, Ismail A (1983) The intracellular peptide-hydrolases of Lactobacillus plantarum. Lait 63, 1-14

El Soda M, Fatallah S, Ezzat N, Desmazeaud MJ, Abou Donia S (1986a) The esterolytic and lipolytic activities of lactobacilli. I. Detection of the esterase system of Lactobacillus casei, Lactobacillus plantarum, Lactobacillus brevis and Lactobacillus fermentum. Sci Aliments 6, 545-557

El Soda M, Korayem M, Ezzat N (1986b) The esterolytic and lipolytic activities of lactobacilli. III. Detection and characterization of the lipase system. Milchwissenschaft 41, 353-355

El Soda M, Desmazeaud MJ, Le Bars D, Zevaco C (1986c) Cell-wall-associated proteinases in Lactobacillus caseiand Lactobacillus plantarum. J Food Prot 49, 361-365

Fryer TF, Reiter B, Lawrence RC (1967) Lipolytic activity of lactic acid bacteria. J Dairy Sci 50, 388-389 
Harper WA, De Cartil C, Chen J (1980) Esterases of lactic streptococci and their stability in cheese slurry systems. Milchwissenschaft 35, 129-132

Kandler O, Weiss N (1986) Genus Lactobacillus Beijerinck $1901,212^{\mathrm{AL}}$. In: Bergey's Manual of Systematic Bacteriology (Sneath PA, Mair NS, Sharpe ME, Holt JG, eds) The Williams \& Wilkins Co, Baltimore

Khalid NM, Marth EH (1990) Proteolytic activity by strains of Lactobacillus plantarum and Lactobacillus casei. J Dainy Sci 73, 3068-3076

Laemmli UK (1970) Cleavage of structural proteins during the assembly of the head of bacteriophage T4 . Nature 227, 680-685

Law BA, Castanon M, Sharpe ME (1976) The effect of non-starter bacteria on flavor development in Cheddar cheese. J Dairy Res 43, 117-125

Litopoulou-Tzanetaki E, Tzanetakis N (1992) Microbiological study of white-brined cheese made from raw goat milk. Food Microbiol 9, 13-19

Miller GC, Mackinnon K (1974) Peptidase mutants of Salmonella typhimurium. J Bacteriol 120, 355-363

Oterholm A, Ordal ZJ, Witter LD (1968) Glycerol ester hydrolase activity of lactic acid bacteria. Appl Microbiol 16, 524-527

Oterholm A, Witter LD, Ordal ZJ (1972) Purification and properties of an acetyl ester hydrolase (acetylesterase) from Lactobacillus plantarum. J Dairy Sci55, 8-13

Peterson SD, Marshall RT, Heyman H (1990) Peptidase profiling of lactobacilli associated with Cheddar cheese and its application to identification and selection of strains for cheese ripening studies. J Dairy Sci. $73,1454-1464$
Sharpe ME (1979) Identification of lactic acid bacteria. In: Identification Methods for Microbiologists (Skinner FA, Lovelock DW, eds) Academic Press, London

Sharpe ME, Fryer TF (1965) Media for lactic acid bacteria. Lab Pract 6, 697-701

Singh A, Srinivasan RA, Dudani AT (1973) Studies on exocellular and endocellular lipases of some of the lipolytic bacteria. Milchwissenschaft 28, 164-166

Thomas TD (1987) Cannibalism among bacteria found in cheese. NZJ Dairy Sci Technol 22, 215-219

Tsakalidou E, Manolopoulou E, Kabaraki E, Zoidou E, Pot B, Kersters K, Kalantzopoulos G (1994) The combined use of whole-cell protein extracts for the identification (SDS-PAGE) and enzyme activity screening of lactic acid bacteria isolated from traditional Greek dairy products. Syst Appl Microbiol 17, 444-458

Turner KW, Lawrence RC, Lelievre J (1986) A microbiological specification for milk for aseptic cheese making. NZ J Dairy Sci Technol 21, 249-254

Tzanetakis N (1990) Microbiological and physicochemical characteristics of two traditional Greek cheeses. Microbiol Aliment Nutr 8, 281-288

Tzanetakis N, Litopoulou-Tzanetaki E (1992) Changes in numbers and kinds of lactic acid bacteria in Feta and Teleme, two Greek cheeses from ewes' milk. J Dairy Sci 75, 1389-1393

Tzanetakis N, Litopoulou-Tzanetaki E, Manolkidis K (1987) Microbiology of Kopanisti a traditional Greek cheese. Food Microbiol 4, 251-256 